\title{
Satysfakcja z pracy i jej wyznaczniki a poczucie jakości życia urzędników
}

\author{
Job satisfaction and its predictors, and the sense of life \\ quality among white-collar workers
}

Streszczenie: Głównym celem badania było określenie poziomu różnych aspektów satysfakcji z pracy urzędników oraz sprawdzenie, w jakim stopniu satysfakcja z pracy wyznaczana jest przez wymiary klimatu psychologicznego (bezpieczeństwo psychiczne i znaczenie pracy). Ponadto poszukiwano wyznaczników poczucia jakości życia. Badaniem objęto 207 polskich pracowników. Uczestnicy rekrutowali się z urzędów administracji publicznej. Badanie ujawniło, że: 1) urzędnicy w pracy najbardziej zadowoleni są z pewności zatrudnienia i relacji ze współpracownikami, najmniej zaś z wynagrodzenia, 2) klimat psychologiczny w istotny sposób wyznacza satysfakcję z pracy, 3) satysfakcja z pracy jest istotnym predyktorem poczucia jakości życia w grupie badanych.

Słowa kluczowe: satysfakcja z pracy, poczucie jakości życia, klimat psychologiczny

Summary: The main objective of this research was to determine the level of different aspects of job satisfaction among white-collar workers and to examine how dimensions of psychological climate (psychological safety and psychological meaningfulness) affect job satisfaction. The author also searched for determinants of quality of life. The data for this study were collected from 207 Polish employees. The participants were recruited from public administration offices. The research has shown that: 1) white-collar workers are most satisfied with the stability of employment and interactions with coworkers, and the least satisfied with remuneration, 2) psychological climate has a significant influence on job satisfaction, 3) job satisfaction is a significant predictor of the sense of life quality among the respondents.

Keywords: job satisfaction, the sense of life quality, psychological climate 


\section{0 | Agata Wołowska}

Jakość życia zawodowego doświadczana przez pracowników jest obszarem szczegółowych dociekań naukowych podejmowanych przez badaczy od wielu lat. Pojęciem $\mathrm{z}$ tego obszaru, które szczególnie często pozostaje w centrum uwagi jest satysfakcja z pracy (job satisfaction), opisywana jako jeden z najważniejszych wyznaczników jakości życia zawodowego.

Z uwagi na fakt, że aktywność zawodowa w miejscu pracy stanowi zasadniczy aspekt życia dla większości ludzi i jako źródło satysfakcji z pracy może przyczynić się do wzrostu zadowolenia z życia - poznanie jej uwarunkowań wydaje się mieć szczególne znaczenie.

\section{Poczucie jakości życia}

Poczucie jakości życia jest istotnym elementem oceny własnej egzystencji dla każdego człowieka. Na przestrzeni lat przyjmowano różne sposoby rozumienia tego pojęcia. Ujmowano je jako: 1) zakres odczuwanego szczęścia, satysfakcji, ogólnego zadowolenia z życia, 2) zakres, w jakim jednostki mogą realizować swoje potrzeby i dążenia, 3) poziom i powiązanie możliwości pełni własnego rozwoju oraz zadowolenia życiowego (Krause, Żyta i Nosarzewska, 2010), lub 4) ogólna ocena zadowolenia z własnych osiągnięć i warunków życia (Diener, Emmons, Larsen i Griffin, 1985).

W podejściach do jakości życia należy uwzględnić także pragmatyczną perspektywę ujęcia tego zagadnienia (Kowalik, 2000). Jakość życia w tej perspektywie traktowana jest jako: 1) mało jednoznaczny zbiór wskaźników, które podlegają modyfikacjom pod wpływem wprowadzanych zmian w życiu pojedynczych ludzi lub całych grup społecznych; 2) w psychologii utożsamiana jest $\mathrm{z}$ zadowoleniem $\mathrm{z}$ życia; 3) sprowadzana jest w końcu do stopnia zaspokojonych potrzeb ludzkich.

Wśród potrzeb ważnych, a związanych $\mathrm{z}$ warunkami środowiskowymi wymienia się: a) potrzebę bezpieczeństwa, odnoszoną do zagrożeń sytuacji ekonomicznej, takich jak lęk o utratę pracy, o zabezpieczenie starości, zagrożenia fizyczne - przez powszechny wzrost przestępczości i ogólnej agresywności, oraz poczucie zagrożenia ze strony wielkich organizacji; b) potrzebę samorealizacji - głównie rozumianej jako satysfakcja płynąca z pracy; c) potrzebę utrzymania określonej równowagi w zakresie napięć psychicznych nadmierne stresy i poczucie znikomości działania jednostkowego; d) potrzebę uznania społecznego związanego przede wszystkim z istnieniem grupy, z którą jednostka może się identyfikować (Gałęski, 1977; za: Smoleń, 2011). 
W niniejszym badaniu poczucie jakości życia rozumiane jest jako deklaracja podmiotu dotycząca ogólnego zadowolenia z własnego życia.

\section{Satysfakcja z pracy}

Satysfakcja z pracy jest jedną z najczęściej analizowanych postaw z obszaru psychologii pracy i organizacji. Według A. Bańki (2000, s. 329) „jest uczuciową reakcją przyjemności lub przykrości, doznawaną w związku z wykonywaniem określonych zadań, funkcji oraz ról”. Jest to stan afektywny związany z zaspokojeniem wewnętrznych (np. poczucie odpowiedzialności, osiągnięcia, itp.) i zewnętrznych (np. komfortowe warunki pracy, dobre relacje interpersonalne, uczciwa płaca itp.) potrzeb jednostki w pracy. Poziom satysfakcji z pracy określać mogą również sądy osoby na temat wykonywanej pracy i stosunek do niej (Zalewska, 2003; za: Łaguna, 2012).

Satysfakcję z pracy można scharakteryzować zarówno jako ogólne zadowolenie jak i zadowolenie partykularne (cząstkowe). W pierwszym przypadku, zadowolenie wiąże się z ogólną uczuciową postawą wobec pracy, nie uwzględniając konieczności zaistnienia związku między poszczególnymi czynnikami pracy. Zadowolenie partykularne to specyficzny rodzaj przyjemności odnoszący się jedynie do jakiegoś konkretnego czynnika pracy, przy czym poszczególne czynniki mogą być od siebie niezależne (Derbis i Bańka, 1998), a każdy z nich stanowić sam w sobie źródło innego aspektu satysfakcji z pracy. W większości prac elementy składające się na zestaw cząstkowych czynników zadowolenia z pracy to przede wszystkim: wymagania stawiane przez pracę (przy pełnym zrealizowaniu nawet najbardziej wymagającej pracy pojawia się satysfakcja), stopień obciążenia fizycznego (wyczerpująca praca nie daje zadowolenia), indywidualna atrakcyjność pracy (interesująca praca daje poczucie satysfakcji), struktura nagród (nagrody i natychmiastowe wzmocnienia są źródłem zadowolenia), cel pracy (jeśli warunki pracy sprzyjają osiągnięciu obranego celu to pojawia się satysfakcja), współpracownicy (zgodny zespół realizujący wspólne cele i osiągający nagrody sprzyja powstawaniu poczucia zadowolenia), styl zarządzania (praca w firmach dbających aby pracownicy dobrze realizowali cele jednocześnie eliminujących konflikty i niejednoznaczność ról jest postrzegana jako bardziej satysfakcjonująca) oraz wynagrodzenie i klimat organizacyjny (Schneider, 1990; za: Bańka, 2000). Czynniki z pola pozazawodowego istotnie wpływające na zadowolenie z pracy to przede wszystkim: struktura Ja (wysoka ocena wiąże się z zadowoleniem z pracy), wiek, życie rodzinne pracownika oraz status społeczny. 


\section{2 | Agata Wołowska}

Istnieje wiele teorii, które ewoluując starały się poznać i opisać uwarunkowania satysfakcji z pracy. Jedną z najwcześniejszych podejmujących ten problem teorii - była teoria higieny-motywacji (motivation-hygiene theory) Herzberga (1957; za: Moyle, Skinner, Rowe i Gork, 2003). Herzberg podkreślał znaczenie zmiennych motywacji oraz higieny, które traktował jako podstawowe determinanty satysfakcji pracowniczej. Wśród składowych czynnika motywacji wyróżnił: dokonania (achievement), uznanie (recognition), pracę samą w sobie (the work itself) oraz odpowiedzialność (responsibility), natomiast do czynników higieny zaliczył: politykę organizacji i administrację (company policy and administration), superwizję (supervision), warunki pracy (working conditions), wynagrodzenie (salary) oraz status (status). Herzberg dowodził, że poziom satysfakcji pracowniczej wynika z obecności czynników motywacyjnych oraz absencji czynników higieny. Późniejszą teorią koncentrującą się na identyfikowaniu determinant zadowolenia z pracy jest teoria związana $\mathrm{z}$ pojęciem personalnego dopasowania do środowiska Hollanda (1985, za: Moyle i in., 2003), który zwrócił uwagę na rolę atmosfery środowiska pracy w budowaniu satysfakcji pracowniczej.

Wysoki poziom satysfakcji z pracy powinien leżeć $\mathrm{w}$ interesie pracodawcy, ponieważ jego obecność pozytywnie koreluje z cechami tzw. „dobrego pracownika". I tak np. Arnold i Feldman (1982) udowodnili, że wysoki poziom satysfakcji pozytywnie koreluje z produktywnością (productivity) oraz negatywnie z absencją w pracy (absenteeism). Jedną z teorii łączących zadowolenie z pracy (job satisfaction) z produktywnością jest koncepcja Marcha i Simona (1958). Opiera się ona za założeniu, że produktywność jest funkcją dwóch zmiennych: stopnia doświadczanego niezadowolenia oraz spostrzeganej instrumentalności wykonywanych zadań pracy względem cenionych nagród. (Bańka, 2000). Nieco bardziej skrajne podejście reprezentuje model Lawera i Portera (1967), w którym wydajność (produktywność) miałaby być przyczyną satysfakcji z pracy, a nie odwrotnie. Zgodnie z tym twierdzeniem poprzez efektywne wykonywanie zadań i osiąganie określonych celów (nagród) jednostka uzyskuje zadowolenie z pracy. Teoria ta ma jednak najlepsze zastosowanie w wypadku zachowań organizacyjnych pracowników na stanowiskach kierowniczych, mając niewielkie odniesienie do pracowników szeregowych lub wykonujących monotonne czynności.

Bardziej skomplikowane w interpretacji niż w przypadku produktywności są wyniki badań dotyczących związku między satysfakcją z pracy a fluktuacją (rotacją) i wspomnianą wcześniej absencją pracowników. Dość oczywistym wnioskiem jest fakt, że osoby mniej zadowolone z pracy charakteryzują się większą liczbą nieobecności, częściej też szukają innej pracy. 
W przypadku absencji należy zwrócić uwagę głównie na jej związek z cząstkowymi czynnikami zadowolenia, natomiast zjawisko fluktuacji należy rozpatrywać w nieco szerszym kontekście. Decyzja o zmianie pracy (bądź jej porzuceniu) nigdy nie jest podejmowana $\mathrm{w}$ oparciu tylko o poziom satysfakcji z wykonywanej pracy. Wpływ na taką decyzję ma w dużym stopniu wiek pracownika, struktura jego osobowości, oraz jego obecna sytuacja materialna czy rodzinna (Derbis i Bańka, 1998). Osoby młode, bez zobowiązań (osobistych i finansowych) w sposób bardziej zdecydowany będą podchodziły do ryzyka związanego z odejściem z miejsca pracy, niż osoby w wieku średnim, posiadające rodzinę i obciążenia finansowe w postaci kredytów. Mobley (1982) w swoich badaniach wykazał, że decyzja o zmianie pracy jest procesem wieloetapowym, obejmującym ciągłe kalkulacje zysków i strat, a poziom satysfakcji z pracy jest tylko jedną z wielu okoliczności wpływających na ostateczny kształt decyzji. W tym wypadku dużo istotniejszą determinantą okazuje się aktualna sytuacja na rynku pracy oraz stopa bezrobocia (Burchell, 1992).

\section{Klimat psychologiczny}

Klimat psychologiczny (psychological climate) oznacza sposób, w jaki środowisko organizacyjne jest spostrzegane i interpretowane przez jego pracowników (James i James, 1989). Według Jamesa i Jamesa spostrzeganie środowiska organizacyjnego nabiera dla pracownika osobistego motywacyjnego i emocjonalnego znaczenia poprzez proces „ewaluacji”, którego on dokonuje. W procesie tym poznawcza reprezentacja cech środowiska jest interpretowana w świetle wartości indywidualnych, a także ze względu na jej istotność dla dobrostanu jednostki. Tak, więc klimat psychologiczny jest raczej cechą indywidualną aniżeli organizacyjną, mierzącą jego psychologiczne znaczenie dla jednostki a nie cechy szczególnej organizacji (por. Wołowska, 2013).

Różnice w spostrzeganiu i ocenie, które konstytuują klimat psychologiczny wynikają zarówno $\mathrm{z}$ różnic indywidualnych między pracownikami, $\mathrm{z}$ różnic sytuacji (np. cechy środowiska organizacyjnego), jak również z interakcji między jednostką i sytuacją (James, James i Ashe, 1990; za: Brown i Leigh, 1996). Spostrzegane związki i inne czynniki indywidualne mogą generować różnice $\mathrm{w}$ spostrzeganiu tego samego środowiska u różnych jednostek. Np. badania poświęcone wymianie między zwierzchnikiem a podwładnym ujawniają różnice $\mathrm{w}$ spostrzeganiu środowiska organizacyjnego nawet wśród pracowników, którzy podlegają temu samemu kierownikowi. 


\section{4 | Agata Wołowska}

Ten sam kierownik może $\mathrm{w}$ różny sposób traktować podwładnych ze względu na czynniki zakotwiczone we wzajemnej relacji, jak również z uwagi na spostrzegane u pracowników różnice w poziomie ich zdolności i gotowości do poświęcania się na rzecz osiągania celów organizacyjnych (Dienesch i Liden, 1986). Dodatkowe różnice w ocenie klimatu psychologicznego mogą być rezultatem różnych stylów zarządzania wewnątrz organizacji jak również różnic kultur w różnych organizacjach.

Operacyjna definicja klimatu psychologicznego przyjęta na użytek badania opiera się na etnograficznych badaniach Kahna (1990), który opisał czynniki klimatu determinujące tendencję pracownika do całkowitego angażowania się w swoją pracę lub psychologicznego dystansowania się od niej. Według Kahna (1990) ważnymi elementami, które podnoszą zaangażowanie pracownika jest bezpieczeństwo psychiczne (psychological safety) oraz psychiczne znaczenie pracy (psychological meaningfulness). Wymiary bezpieczeństwa i znaczenia pracy stanowią wyższy poziom uporządkowania znaczeniowego określającego interpretację ważności środowiska organizacyjnego przez pracownika dla jego osobistego dobrostanu (Brown i Leigh, 1996).

Kahn (1990) definiuje psychiczne bezpieczeństwo jako poczucie pracownika, że może on uzewnętrzniać swoje Ja bez obawy, że pociągnie to za sobą negatywne konsekwencje dla jego obrazu siebie, statusu lub kariery. Wymiary klimatu, które składają się na psychiczne bezpieczeństwo to: (a) kierownictwo, które spostrzegane jest jako elastyczne i wspierające, dające pracownikom poczucie, że mają kontrolę nad własną pracą i metodami, które stosują do jej wykonania (supportive management), (b) role i normy organizacyjne, które spostrzegane są jako klarowne (clarity), (c) poczucie wolności pracownika w wyrażaniu własnych, prawdziwych uczuć i rdzennych aspektów Ja w roli zawodowej (self-expression). Natomiast znaczenie pracy jest poczuciem pracownika, że w zamian za inwestowanie otrzymuje się zwrotnie psychiczną, poznawczą lub emocjonalną energię. Ludzie doświadczają poczucia znaczenia swojej pracy wówczas, gdy spostrzegają ją jako wyzwanie, jako wartą zachodu i przynoszącą satysfakcję. Wymiary klimatu psychologicznego, które konstytuują psychiczne znaczenie pracy obejmują: (a) poczucie tworzenia znaczącego wkładu, który przyczynia się do osiągania organizacyjnych celów (perceived meaningfulness of contribution), (b) poczucie, że organizacja adekwatnie uznaje wkład pracy (recognition), (c) poczucie, że praca jest wyzwaniem i prowadzi do rozwoju osobistego (challenge). 


\section{Problematyka badawcza}

Głównym celem prezentowanego badania było określenie poziomu różnych aspektów satysfakcji z pracy urzędników oraz sprawdzenie, w jakim stopniu satysfakcja z pracy wyznaczana jest przez czynniki klimatu psychologicznego, tj. bezpieczeństwo psychiczne i znaczenie pracy. Celem badania było również ustalenie czy satysfakcja z pracy jest predyktorem poczucia jakości życia w grupie pracowników urzędów.

Poszukując wyznaczników satysfakcji z pracy przyjęto założenie, że pozytywna ocena klimatu psychologicznego w miejscu pracy będzie wiązała się $\mathrm{z}$ wyższym jej poziomem, a ponadto, że satysfakcja z pracy będzie sprzyjała zadowoleniu z życia.

\section{Metoda}

\section{CHARAKTERYSTYKA OSÓB BADANYCH I PROCEDURA BADANIA}

Badaniem objęto 207 osób. Byli to pracownicy urzędów pracy zatrudnieni na terenie województwa kujawsko-pomorskiego. W badanej próbie były 154 kobiety i 53 mężczyzn, w wieku od 20 do 57 lat. Niemal 20\% badanych miało wykształcenie średnie, pozostałe $80 \%$ to badani z wykształceniem wyższym. Staż pracy ogółem wahał się od roku do 39 lat, natomiast staż w obecnym miejscu pracy zawierał się w przedziale od roku do 27 lat. Osoby badane indywidualnie wypełniały zestaw kwestionariuszy dostarczony im do miejsca pracy. Zostały one poinformowane o celu badania oraz dobrowolności wypełnienia materiałów. Jednocześnie wszyscy uczestnicy zostali zapewnieni o całkowitej anonimowości badania.

NARZĘDZIA

Satysfakcja z pracy

Poziom satysfakcji z pracy mierzono Skalą Satysfakcji z Pracy (Bettencourt, Gwinner i Meuter, 2001) w opracowaniu Wołowskiej (2013). Skala zawiera 9 pozycji - określeń różnych aspektów pracy zawodowej (np. Wjakim stopniu zadowolony jesteś z osobistego rozwoju, jaki daje tobie praca, lub Wjakim stopniu zadowolony jesteś z ludzi, z którymi pracujesz), do których badany ustosunkowuje się przy pomocy 7 stopniowej skali typu Likerta. Jako wskaźnik satysfakcji z pracy przyjęto średni wynik z pozycji skali. 


\section{6 | Agata Wołowska}

Klimat psychologiczny

Kwestionariusz Klimatu Psychologicznego opracowano w oparciu o oryginalne narzędzie Browna i Leighta (Psychological Climate Measure) (Brown i Leight, 1996; por. Wołowska, 2013). Wymiary kwestionariusza składają się w dwa teoretycznie wyróżnione aspekty klimatu psychologicznego - bezpieczeństwo psychiczne i znaczenie pracy. Pierwsze trzy wymiary, tj. wsparcie ze strony kierownictwa (np. „Mój szef jest elastyczny, jeżeli chodzi o sposób realizacji moich celów zawodowych”), jednoznaczność roli (np. „Dyrekcja bardzo wyraźnie określiła, w jaki sposób mam wykonywać swoją pracę") oraz wyrażanie siebie (np. „Uczucia, które wyrażam w pracy są moimi prawdziwymi uczuciami”) składają się na aspekt bezpieczeństwa psychicznego, kolejne trzy, tj. uczestnictwo (np. „Czuję się bardzo przydatny w mojej pracy”), uznanie (np. „Firma uznaje znaczenie mojego wkładu pracy”) i wymagania (np. „Moja praca jest bardzo wymagająca”) konstytuują aspekt znaczenia pracy. Każda z 18 pozycji kwestionariusza oceniana jest przez badanych na siedmiostopniowej skali (od 1 - zupełnie nie zgadzam się, do 7 - całkowicie się zgadzam).

\section{Poczucie jakości życia}

W niniejszym badaniu metodą jego pomiaru była Drabinka Cantrila - globalna ocena życia (Ladder, Cantril, 1965; za: Derbis i Bańka, 1998). Jest to 11 stopniowa skala (0-10), graficznie przedstawiona w formie drabinki, na której osoby badane zaznaczają stopień satysfakcji z własnego życia, wybierając szczebel pomiędzy „najgorsze życie jakie może się zdarzyć” a "najlepsze życie jakie może się zdarzyć”.

\section{Wyniki}

Analizy wstępne

Dla każdej badanej zmiennej policzono statystyki opisowe - średnią i odchylenie standardowe, a także sprawdzono korelacje między zmiennymi oraz rzetelności stosowanych w badaniu skal (por. Tabela 1). Z przeprowadzonych analiz wynika, że stosowane skale uzyskały wysoką, satysfakcjonującą rzetelność zdecydowanie powyżej poziomu 0.80 współczynnika alfa Cronbacha, co pozwala traktować pomiary zmiennych jako rzetelne.

Wyniki analiz ujawniły ponadto, że badane zmienne - zgodnie $\mathrm{z}$ założeniami - są ze sobą związane w stopniu umiarkowanym bądź wysokim. Jak widać w Tabeli 1, uzyskano wyniki świadczące o silnej zależności między sa- 
tysfakcją z pracy i wymiarami klimatu psychologicznego, tj. ze znaczeniem pracy i bezpieczeństwem psychicznym - współczynnik $r$ Pearsona wyniósł odpowiednio $(, 62)$ i (,61). Natomiast przeciętnie wysoką korelację uzyskano między satysfakcją z pracy i zadowoleniem z życia $(r=, 44)$.

Tabela 1. Średnie, odchylenia standardowe, wskaźniki zgodności wewnętrznej ( $\alpha$ Cronbacha) i interkorelacje (r Pearsona) mierzonych zmiennych

\begin{tabular}{lcccccc}
\hline & $M$ & SD & 1. & 2. & 3. & 4. \\
\hline 1. Zadowolenie z życia & 6,34 & 1,53 & - & & & \\
2. Satysfakcja z pracy & 41,53 & 9,92 &, $44^{* *}$ & $\alpha=0,89$ & & \\
3. Bezpieczeństwo psychiczne & 48,95 & 10,87 &, $32^{* *}$ &, $61^{* \star}$ & $\alpha=0,90$ & \\
4. Znaczenie pracy & 37,77 & 8,86 &, $30^{* *}$ &, $62^{* \star}$ &, $79^{* *}$ & $\alpha=0,90$ \\
\hline
\end{tabular}

${ }^{*} p<0,05 ;{ }^{* *} p<0,01$

Poziom czastkowych satysfakcji z pracy

Do określenia poziomów cząstkowych satysfakcji z pracy zastosowano analizę wariancji w układzie: 2 Płeć x 9 Wymiary satysfakcji z pracy, z powtarzanym pomiarem w obrębie drugiego czynnika. Analiza ujawniła efekt główny czynnika Płeć: $F(1,202)=7,55 ; p<0,006$ (kobiety - urzędniczki uzyskały wyższe wyniki na wszystkich wymiarach satysfakcji z pracy: kobiety $M=4,74$, mężczyźni $\mathrm{M}=4,26$ ) oraz efekt główny czynnika Wymiary satysfakcji z pracy: $F(8,1616)=58,87, p<0,001$.

Jak pokazuje Ryc. 1, urzędnicy uzyskali najwyższe wyniki na wymiarze - stałość zatrudnienia ( $M=5,14)$ i relacje z pracownikami $(M=5,36)$, najniższy zaś na wymiarze - wynagrodzenie $(\mathrm{M}=2,89)$ (istotność statystyczną wyników zweryfikowano testem Bonferoniego; nie stwierdzono istotnej interakcji czynników). 
Ryc. 1. Poziom cząstkowych satysfakcji z pracy w grupie badanych urzędników

Wykres średnich $F(8,1616)=58,867 ; p=0,0000$

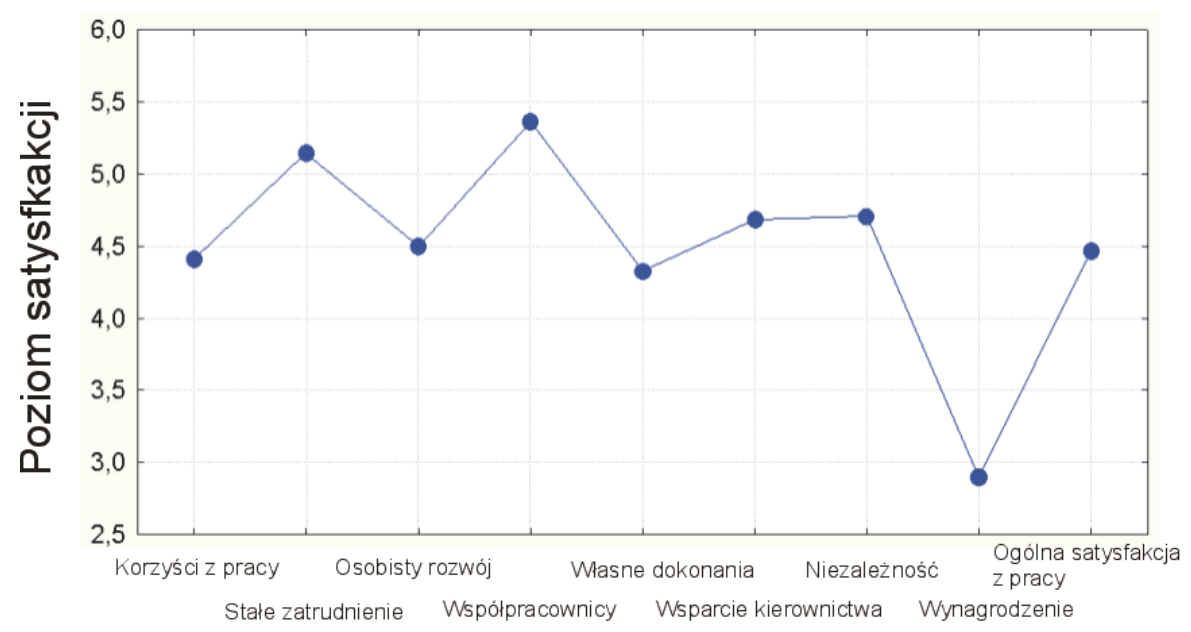

R1

Źródło: badanie własne

Predyktory satysfakcji z pracy i zadowolenia z życia

W celu sprawdzenia przewidywania, że klimat psychologiczny, tj. bezpieczeństwo psychiczne i znaczenie pracy istotnie nasilają (przewidują) satysfakcję z pracy wykonano analizę regresji. Analogiczną analizę zastosowano dla ustalenia, czy satysfakcja z pracy wyznacza zadowolenie z życia pracowników urzędów.

Przeprowadzona analiza wykazała, że satysfakcja z pracy urzędników wyjaśniana jest w badanym modelu na poziomie $41 \%\left(R=, 64, R^{2}=, 41\right.$, $p<, 001)$. Silniejszym predyktorem dla satysfakcji z pracy jest bezpieczeństwo psychiczne niż znaczenie pracy (por. Ryc. 2).

Analiza z uwzględnieniem płci ujawniła, że satysfakcja z pracy u kobiet wyjaśniana jest na poziomie $51 \%\left(R=, 71, R^{2}=, 51, p<, 001\right)$. Silniejszym predyktorem satysfakcji z pracy u kobiet okazało się znaczenie pracy niż bezpieczeństwo psychiczne, natomiast u mężczyzn satysfakcja z pracy wyjaśniana jest na poziomie $18 \%\left(R=, 42, R^{2}=, 18, p<, 01\right)$, a istotnym jej predyktorem jest tylko znaczenie pracy (por. Ryc. 3 ). 
Ryc. 2. Predyktory satysfakcji z pracy pracowników urzędów

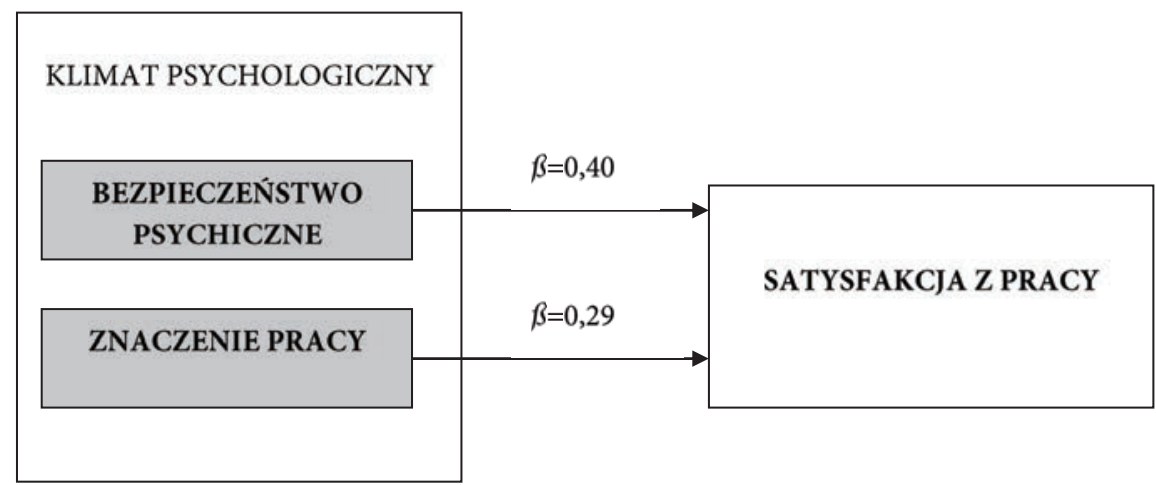

Ryc. 3. Predyktory satysfakcji z pracy pracowników urzędów w grupie kobiet i mężczyzn

KOBIETY

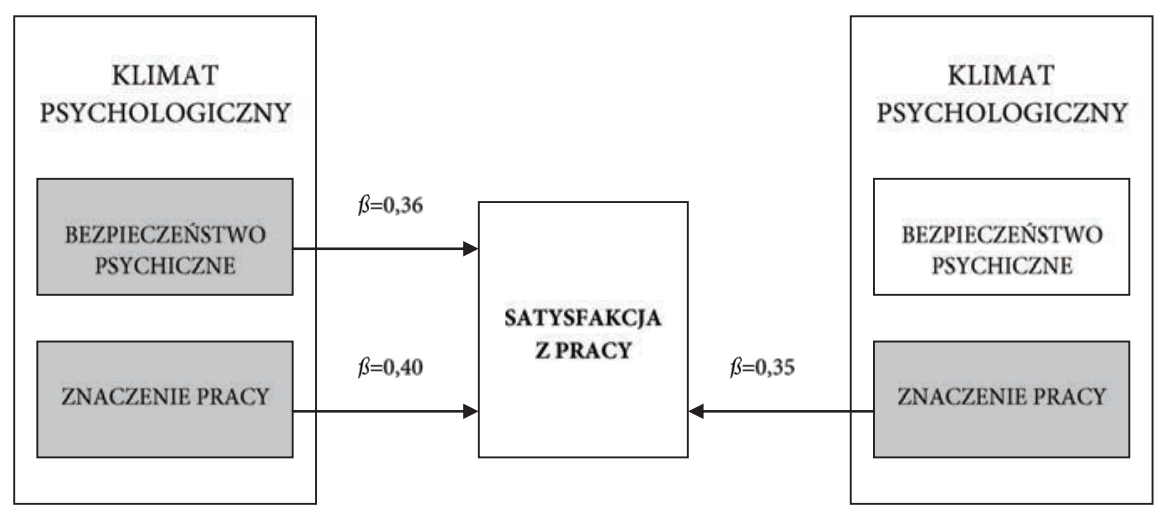

Analizy potwierdziły również, że satysfakcja z pracy (poza zaangażowaniem $\mathrm{w}$ pracę ${ }^{2}$ ) jest istotnym predyktorem zadowolenia z życia urzędników, które zostało wyjaśnione w badanym modelu na poziomie $19 \%(R=, 43$, $R^{2}=, 18, p<, 001$ ) (por. Ryc. 4).

2 Opis tej zmiennej został w niniejszym artykule celowo pominięty ze względu na obszerne jego opracowanie w wydanej wcześniej publikacji (por. Wołowska, Bańka i Bazińska, 2010). 
Ryc. 4. Satysfakcja z pracy jako predyktor zadowolenia z życia pracowników urzędów

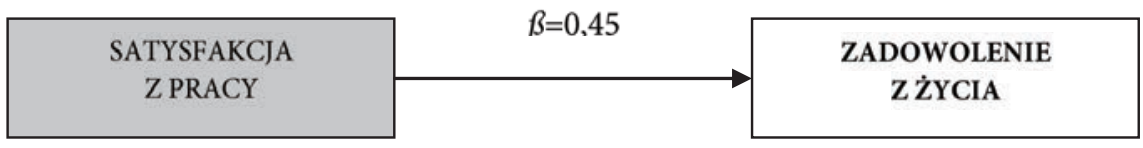

\section{Podsumowanie}

Wyniki badania ujawniły, że urzędnicy są w pracy najbardziej zadowoleni z poczucia bezpieczeństwa, jakie daje im stałość zatrudnienia, jak również z relacji ze współpracownikami, najmniej zaś z wynagrodzenia. Wydaje się to trafnie odzwierciedlać trudną sytuację panującą obecnie na rynku pracy, w której praca stała się dobrem niedostępnym dla każdego - dobrem, o które trzeba walczyć i bardzo się starać, aby go nie stracić. Niski wzrost gospodarczy oraz rosnąca stopa bezrobocia przekładają się bezpośrednio na postawy pracowników. Coraz bardziej obawiają się oni, że jeśli zostaną zwolnieni, długo nie będą mogli znaleźć nowego zatrudnienia.

Potrzeba stałości i pewności zatrudnienia jest przejawem bardziej ogólnej utrzymującej się w ostatnich latach w badaniach polskich tendencji (por. Bańka i Wołowska, 2006; Wołowska, 2005), która pokazuje, że kontynuowanie zatrudnienia $\mathrm{w}$ obecnym miejscu pracy jest sposobem zapewniania sobie przez pracowników poczucia bezpieczeństwa - pozostawanie w jakiejkolwiek organizacji jest lepsze niż bycie bezrobotnym. Nawet ci pracownicy, którzy nie są zadowoleni z warunków pracy (np. niska pensja), nie przejawiają chęci zmiany firmy, gdyż niepewność na rynku pracy sprawiła również, że obniżyły się nasze oczekiwania względem poziomu wynagrodzenia.

Poszukując predyktorów satysfakcji z pracy, zgodnie z przewidywaniami wyniki pokazały, że w sposób istotny na jej poziom wpływa klimat psychologiczny. W grupie badanych urzędników silniejszym predyktorem dla satysfakcji z pracy okazało się bezpieczeństwo psychiczne niż znaczenie pracy, co oznacza, że satysfakcja z pracy w badanej grupie wyjaśniana jest przede wszystkim spostrzeganiem przez pracownika kierownictwa jako wspierającego, klarownością roli zawodowej, a także poczuciem wolności w wyrażaniu siebie. Analizy, w których uwzględniono płeć badanych ujawniły ponadto, że ten wymiar klimatu psychologicznego wyjaśnia satysfakcję z pracy tylko w grupie kobiet. Natomiast drugi jego wymiar, tj. znaczenie pracy wyjaśnia satysfakcję z pracy zarówno u kobiet, jaki i u mężczyzn, co może sugerować, że pracownicy, którzy mają poczucie, że w zamian za inwestowanie w firmę 
otrzymują psychiczną, poznawczą lub emocjonalną energię są jednocześnie bardziej z niej zadowoleni. Wynik ten pokazuje ponadto, że poczucie pracownika, iż tworzy on znaczący wkład przyczyniający się do osiągania organizacyjnych celów - wkład, który jest doceniany przez zwierzchników oraz spostrzeganie pracy jako wyzwania, które prowadzi do rozwoju osobistego pracownika - nasilają jego satysfakcję z pracy.

Praktycznym wnioskiem płynącym z przeprowadzonego badania jest sugestia, że kadra zarządzająca powinna oddziaływać na klimat psychologiczny w miejscu pracy, gdyż pozytywna jego ocena przez pracownika sprawi, że będzie on bardziej zadowolony z wykonywanej pracy. Ponadto kierownicy urzędów powinni wiedzieć, że aby zwiększyć u pracowników poziom ich satysfakcji z wykonywanych czynności zawodowych muszą oddziaływać na wzrost poczucia znaczenia pracy, a w przypadku kobiet również na wzrost poczucia bezpieczeństwa w miejscu zatrudnienia.

Ostatnim celem badania było sprawdzenie, czy satysfakcja z pracy jest wyznacznikiem zadowolenia z życia u pracowników urzędów. Przeprowadzone analizy dostarczyły wyniki zgodne z oczekiwaniami i wykazały, że satysfakcja z pracy w sposób istotny wpływa na jakość ich życia, co potwierdza, że aktywność zawodowa jest jednym z najważniejszych obszarów aktywności w życiu człowieka.

\section{Bibliografia}

Arnold, H.J., Feldman, D.C. (1982). A multivariate analysis of the determinants of job turnover. "Journal of Applied Psychology", No. 67, p. 350-360.

Bańka, A. (2000). Psychologia organizacji. w: J. Strelau (red.), Psychologia. Podręcznik akademicki (t. 3, s.321-350). Gdańsk: GWP.

Bańka, A., Wołowska, A. (2006). Zmiana rzeczywistości organizacyjnej a postawy wobec pracy: Analiza typów przywiązania i zaangażowania w pracę. w: A. Biela, B. Rożnowski, A. Bańka (red.), Praca i organizacja w procesie zmian. Poznań: Stowarzyszenie Psychologia i Architektura.

Bettencourt, L.A., Gwinner, K.P., Meuter (2001). A comparison of attitude, personality and knowledge predictors of service-oriented organizational citizenship behaviors. "Journal of Applied Psychology", No. 86, 1, p. 29-41.

Brown, S.P., Leigh, T.W. (1996). A new look at psychological climate and its relationship to job involvement, effort, and performance. "Journal of Applied Psychology", No. 81, 4, 358-368. 


\section{2 | Agata Wołowska}

Burchell, B.J. (1992). Towards a social psychology of the labour market: Or why we need to understand the labour market before we can understand unemployment. "Journal of Occupational and Organisational psychology", No. 65, 345-354.

Diener, E., Emmons, R.A., Larsen, R.J. i Griffin, S. (1985). The Satisfaction With Life Scale. "Journal of Personality Assessment", No. 49, 71-75.

Dienesch, R.M., Liden, R.C. (1986). Leader-member exchange model of leadership: A critique and further development. "Academy of Management Review", No. 11, 618-634.

Derbis, R., Bańka, (1998). Poczucie jakości życia a swoboda działania i odpowiedzialność. Poznań: Stowarzyszenie Psychologia i Architektura.

James, L.A., James, L.R. (1989). Integrating work environment perceptions: Explorations into the measurement of meaning. "Journal of Applied Psychology", No. 74, 739-751.

Kahn, W.A. (1990). Psychological conditions of personal engagement and disengagement at work. "Academy of Management Journal", No. 33, 692-724.

Kowalik, S. (2000). Jakość życia psychicznego. w: R. Derbis (red.). Jakość rozwoju a jakość życia. Częstochowa: WSP, 11-32.

Krause, A., Żyta, A., Nosarzewska, S. (2010). Normalizacja środowiska społecznego osób z niepełnosprawnościq̨ intelektualnq̨. Toruń: Wydawnictwo Edukacyjne Akapit.

Lawler, E.E., Porter, L.W. (1967). The effect of performance on job satisfaction. "Industrial Relations", No. 7, 1, 20-28.

Łaguna, M. (2012). Satysfakcja z życia i satysfakcja z pracy a motywacja do podejmowania szkoleń: Doniesienie z badań. „Psychologia Jakości Życia”, nr 12, 2, $163-$ $-172$.

March, J.G., Simon, H.A. (1958). Organizations. New York: John Wiley and Sons.

Mobley, W. H. (1982). Some Unanswered Questions in Turnover Research. "Academy of Management Review", No. 7, 111-116.

Moyle, W., Skinner, J., Rowe, G., Gork, Ch., (2003). Views of job satisfaction and dissatisfaction in Australian long-term care. "Journal of Clinical Nursing”, No. 12, 168-176.

Smoleń, R. (2011). Poczucie jakości życia u młodzieży z upośledzeniem umysłowym. „Zeszyty Naukowe Małopolskiej Wyższej Szkoły Ekonomicznej w Tarnowie”, nr 18, 1, 273-288.

Wołowska, A. (2005). Poczucie jakości życia a przywiązanie pracownika do organizacji. w: A. Bańka (red.), Psychologia jakości życia. Poznań: Stowarzyszenie Psychologia i Architektura.

Wołowska, A., Bańka, A., Bazińska, R. (2010). Wpływ naruszenia kontrakt psychologicznego na zaangażowanie $w$ pracę. Mediacyjna rola klimatu psychologicznego. „Czasopismo psychologiczne”, nr 16, 2, 225-236.

Wołowska, A. (2013). Przywiązanie do organizacji a kontrakt psychologiczny. Toruń: Wydawnictwo Naukowe UMK. 